\title{
Anticonvulsant intoxication precipitated by azapropazone
}

\author{
C. J. C. ROBERTS \\ M.D., M.R.C.P. \\ D. Macfarlane \\ M.B., M.R.C.P.
}
T. K. DANESHMEND
M.B., M.R.C.P.

P. A. DiEPPE

M.B., M.R.C.P.

\section{University of Bristol Departments of Medicine, Pharmacology and Rheumatology, Bristol Royal Infirmary, Bristol BS2 $8 \mathrm{HW}$}

\begin{abstract}
Summary
A patient is reported who developed a hitherto unrecognized drug interaction between azapropazone and anticonvulsants which led to toxicity with the latter. The mechanism of this interaction is discussed.

\section{Introduction}

Anticonvulsant drugs have a low therapeutic ratio so that dosage requirements are critical. Their effects are therefore susceptible to the influences of concurrent medication. In common with the anticonvulsants, the non-steroidal anti-inflammatory drugs tend to be highly protein bound and metabolized in the liver. Thus, potential for interaction between these groups of drugs exists. A case is reported in which such a hitherto unrecognized interaction led to serious toxicity.
\end{abstract}

\section{Case report}

A 41-year-old woman, who had had epilepsy since childhood, presented with sero-positive, erosive rheumatoid arthritis which had developed 3 years before. Her epilepsy was well controlled on phenytoin $100 \mathrm{mg}$ and primidone $250 \mathrm{mg}$ both 3 times daily. The mild rheumatoid arthritis involving her wrists, ankles and small joints of the hands had been treated for 2 years with fenclofenac $1200 \mathrm{mg} /$ day and occasional paracetamol/dextropropoxyphene tablets. A flare-up of arthritis 2 weeks before her hospital admission led to a change from fenclofenac to azapropazone $600 \mathrm{mg}$ twice daily. Over the next few days she became increasingly unsteady and clumsy. For 4 days before her admission she was sleepy and had a headache with episodes of blurred or double vision.

At the time of admission to hospital she was drowsy and slow in her actions, comprehension and speech. Neurological examination revealed general- ized motor ataxia and nystagmus. Except for changes of acute rheumatoid arthritis, the remainder of the physical examination was normal. A clinical diagnosis of phenytoin toxicity was made, and subsequently confirmed by raised serum concentrations of anticonvulsants.

The drug concentrations, adjustments in therapy and changes in clinical toxicity are shown in the figure. Initial reduction in anticonvulsant dose was accompanied by clinical improvement. However, when her previous regimen was reinstated, it was associated with a transient episode of toxicity. Laboratory tests were normal except for a low red cell folate $(83 \mu \mathrm{g} / \mathrm{l}$; normal range $120-640)$, a borderline serum calcium $(2.25 \mathrm{mmol} / 1$; normal range $2 \cdot 25-2 \cdot 70$ ) and an elevated alkaline phosphatase (18 KAu./1; normal range 3-13).

She was discharged from hospital 10 days after admission. Toxicity has not recurred on phenytoin $200 \mathrm{mg}$ and fenclofenac $1200 \mathrm{mg} / \mathrm{day}$, together with folic acid supplements.

\section{Discussion}

Anticonvulsant intoxication was thought to be the cause of this patient's symptoms and signs because plasma anticonvulsant concentrations were high during periods of clinical toxicity and fell with clinical improvement. The onset of intoxication closely followed the change to azapropazone, strongly suggesting a drug interaction. There are 2 possible mechanisms for such an interaction: competition for protein binding sites and impairment of hepatic metabolism. The first is unlikely because, although phenytoin (Richens, 1978) and azapropazone (Jones, 1976) are both $90 \%$ protein bound, in vivo studies of this type of drug interaction have shown that free drug concentrations remain unchanged whilst total plasma levels are reduced 

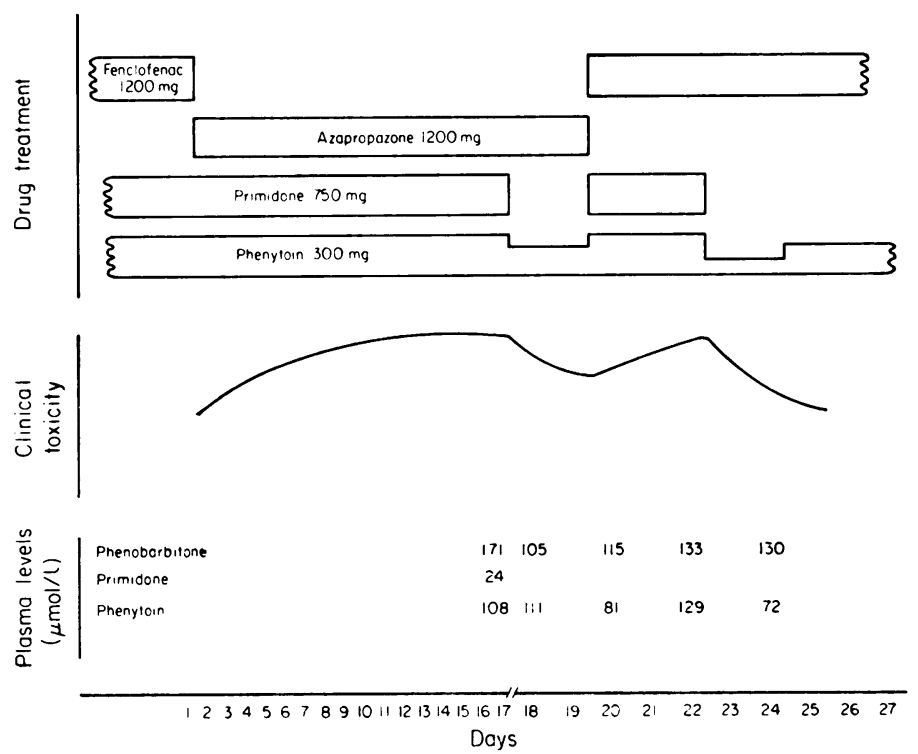

FIG. 1. Changes in drug doses, clinical toxicity and anticonvulsant serum concentrations in a 41-year-old woman. (Therapeutic ranges: phenobarbitone 40 to $130 \mu \mathrm{mol} / \mathrm{l}$; phenytoin 40 to $80 \mu \mathrm{mol} / \mathrm{l}$.)

(Monks and Richens, 1980). Also, neither primidone nor its metabolite phenobarbitone are significantly protein bound (Richens, 1978).

Impairment of hepatic metabolism is a more likely explanation particularly as phenytoin and phenobarbitone concentrations were both raised. Over $40 \%$ of an oral dose of azapropazone is metabolized by hydroxylation (Jones, 1976) in the liver, the remaining $60 \%$ is excreted unchanged in the urine. The related drugs phenylbutazone and oxyphenbutazone have both been reported as competing with phenytoin and phenobarbitone for hepatic hydroxylation (Hansten, 1979). It is therefore quite possible that azapropazone could also compete for these enzyme systems. Low concentrations of serum folate have also been shown to impair the hepatic metabolism of anticonvulsants

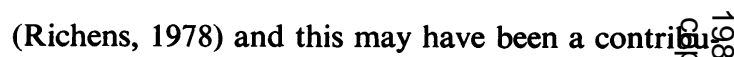
tory factor.

It is concluded that care should be exercised werp prescribing azapropazone to patients receiving anti convulsants.

\section{References}

Hansten, P.D. (1979) Drug Interactions 4th edn, pp. 69-92 Lea and Febiger, Philadelphia.

JONES, C.J. (1976) The pharmacology and pharmacokinetics of azapropazone - a review. Current Medical Research an Opinion, 4, 3.

Monks, A. \& Richens, A. (1980) Effect of single doses of sodium valproate on serum phenytoin levels and proteim binding in epileptic patients. Clinical Pharmacology and Therapeutics, 27, 89.

Richens, A. (1978) Antiepileptic drugs. In: Recent Advance in Clinical Pharmacology (Ed by Turner, P. \& Shando D.G.), Vol. 1. pp. 147-162. 